Investigations

\title{
Features of Distribution, Harmfulness and Control of the Population of the Eriosoma Lanigerum Hausm. (Homoptera, Aphididae) Woolly Aphid in the Nurseries of Ukraine and Kazakhstan
}

\author{
${ }^{1}$ Damira Amirovna Absatarova, ${ }^{2}$ Valentin Fedorovich Drozda, \\ ${ }^{3}$ Gulshariya Nursapayevna Kairova, ${ }^{2}$ Vlad Antonovna Shevchenko, \\ ${ }^{3}$ Saule Bedelbaevna Korabaeva and ${ }^{3}$ Samat Isayevich Isayev \\ ${ }^{1}$ Kazakh National Agrarian University, 050010, Almaty, Kazakhstan \\ ${ }^{2}$ National University of Bioresources and Nature Management of Ukraine, \\ 15, Geroyev Oborony Str., Kiev, 03041, Ukraine \\ ${ }^{3}$ Kazakh Research Institute of Horticulture and Viticulture \\ 050060, 238/5, Gagarin Avenue, Almaty, Kazakhstan
}

\author{
Article history \\ Received: 31-08-2017 \\ Revised: 07-09-2017 \\ Accepted: 16-12-2017 \\ Corresponding Author: \\ Damira Amirovna Absatarova \\ Kazakh National Agrarian \\ University, 050010, Almaty, \\ Kazakhstan \\ E-mail: mikolok.kz@mail.ru
}

\begin{abstract}
The paper presents the results on technology of cultivation of apple-tree saplings and the ways to regulate the phytophage population. The nature of distribution of one of the main nursery pests such as woolly aphid and its specialized entomophage - aphelinus - has been studied. A woolly aphid - typical representative of sucking phytophages - is characterized as a dominant species in the gardens and nurseries of Ukraine and Kazakhstan. Standard methods of research were used in the course of work. Based on the studies, a set of factors forming the structure and dynamics of red woolly aphids in apple tree nurseries has been determined. The natural populations of parasites and predators play an essential role for its population dynamics. The principle possibility of regulating the population and protection of nurseries from woolly aphids using the method of settling the natural populations of the hymenopteran entomophage aphelinus has been established.
\end{abstract}

Keywords: Nurseries, Apple Tree Plantations, Woolly Aphids, Aphelinus, Harmfulness, Plantation Protection

\section{Introduction}

The problem of growth of the gross fruit crops in gardens is resolved primarily through intensification of production, where, in a set of factors, the crop protection from phytophages and phytopathogens is of great importance. Obtaining a quality fruit crops is a very topical problem. The solution to this problem is related to the rational use of the range of pesticides. In subsequent years, the assortment of biological agents in the gardens protection technology - microbiological preparations created on the basis of strains of entomopathogenic bacteria, fungi and viruses - has considerably expanded (Drozda et al., 2013a; 2013b).

Since the planting material grown has a wide geography of supplies within the country and sometimes is exported abroad, in the absence of phytosanitary control the nursery may become a source of propagation of parasites and phytopathogenic microorganisms. In this regard, the issues of phytosanitary and plant protection, monitoring of species that damage cultivated plants in nurseries, are very relevant.

Natural and laboratory cultures of entomophages play an essential role in regulating the population and harmfulness of phytophages. It is known that their species composition in the garden agrocenoses includes more than 1,000 species (Zerova et al., 1991). This global problem is also topical in the seedling production technologies in nurseries. This is the place where the primary foci of such dangerous phytophages as aphids, scabies and herbivorous mites are formed. The existing destructive strategies almost completely destroy natural populations of entomophages and deduce them from the regulatory process (Audemard, 1976). Obviously, it is necessary to develop and implement plant protection technologies and, first of all, garden agrocenoses resting on an ecological basis. 
Studies of many authors carried out in branch institutes have shown the effectiveness and prospectivity of reducing the pesticide press in gardens through the use of microbiological preparations, industrial crops of entomophages, techniques that promote for the conservation, activation and dispersal of natural populations (Boldyrev et al., 1989; Drozda et al., 2014).

It is known that the aphids are included in the number of phytophages of apple gardens characterized by increased harmfulness, including that of the nurseries. More than 30 species of aphids were identified in the fruit plantations, of which 20 cause significant harm, annually or in separate years (Kolesova, 1979). Aphids that damage fruit crops are biologically very heterogeneous. According to a life cycle type, they are divided into species with a full development cycle (monoecious, dioecious) and with an incomplete cycle. The incomplete life cycle or an anolocyclia is characterized by the fact that the amphigonous (egglaying) generation is absent or is a vestigial structure. The woolly aphid (Eriosoma lanigerum Hausm.) is a typical representative of this biological phenomenon. The species, which intensively multiplies, penetrates into new regions where the apple tree is grown.

Specialized literature gives sufficient attention to the biology and ecology of woolly aphids. The biology of the species, its distribution, vital strategy and harmfulness have been studied in detail. However, all this information refers to the fruit-bearing apple gardens (Kolesova, 1979; Vereshchagina, 1957; Vasil'yev and Livshits, 1984). Parasites and predators of aphids are described in sufficient detail (Boldyreva, 1974). There is practically no information about the development of aphids in nurseries.

The purpose of the research was to study the nature of the woolly aphid spread in apple nurseries, the determination and species identification of a specialized aphelinus entomophage. In addition, the task was to scientifically justify and approve the method of expansion on apple seedlings in aphelinus nurseries against the background of different trees' protection technologies. Four-year (2014-2017) studies were conducted in nurseries of Ukraine, Kiev region, in the zone of the Forest Steppe and Polesye, as well as in nurseries of Kazakhstan, Almaty, South Kazakhstan and Zhambyl oblasts.

\section{Methods}

The standard methods adopted in the field of protection of gardens and nurseries have been used in the course of research (Kazanok, 1972) Pests of agricultural crops and forest plantations, 1987; Vereshchagin et al., 1985; Izhevskiy, 1988; Drozda, 2017; Drozda and Sagitov, 2015a). The phytosanitary monitoring has been carried out using visual and instrumental techniques. Active and dead individuals of woolly aphids, its entomophages, accompanying species have been collected. Biomaterial has been evaluated in biological laboratories (Drozda et al., 2014). The level of their viability, infestation by entomophages has been determined. The degree of infection of aphids by entomopathogens has been established. Predators have been collected and fed in the laboratory. Their species identification has been carried out. The level and effectiveness of predation have been determined in the field environment (Leclant, 1974; Bonnemaison, 1974; Rabasse, 1974; Drozda and Sagitov, 2015b).

In autumn, branches with diapausing populations of aphelinus have been prepared. In the spring, during the increment of the first peak of the aphids' population (April-June), one method of the aphelinus expansion into the trees has been used. In total, there were three options. The first option was the chemical standard with the use of pesticides included in the state registers of Ukraine and Kazakhstan. The second option was the integrated protection where the bacterial preparations such as Lepidocid and Dentrobacillin and two trichogram expansion stages were used. In the period of the inception and mass oviposition of leaf rollers the Trichogramma pintoi Voeg. species has been used. The norms of Trichogramma expansion were 2 and 3 thousand species per tree. The third option provided for three stages of aphelinus expansion. The first one occurred in the period of the first peak in the woolly aphids' population. The first stage took place at the beginning of August and the second expansion of the parasite - in 10-12 days.

It was also important that during the vegetation period eight counts of the level of infection of aphids with aphids were conducted. In addition, the level of infection of aphids and other entomophages has been taken into account. To assess the positive result, the most objective and informative test characteristics have been used. The resulting digital material has been statistically processed.

\section{Results}

The studies conducted give the basis to draw the conclusion that the woolly aphids are widespread in nurseries of Ukraine and Kazakhstan (Fig. 1).

Its intensive foci have also been observed in farm gardens, private and abandoned plantings of apple trees. At the same time, as confirmed by our research, the species inhabits and damages the apple tree of all varieties. At joint plantings, within one quarter, small foci of aphids have been observed on pears, quince, juneberry, cotoneaster and rowan. These species of fruit plantations represented the original reservoirs of phytophagous accumulation. Nevertheless, the colonies of woolly aphids were more intensively formed in the forest-steppe zone of Ukraine, taking into account more favorable hydrothermal conditions. 


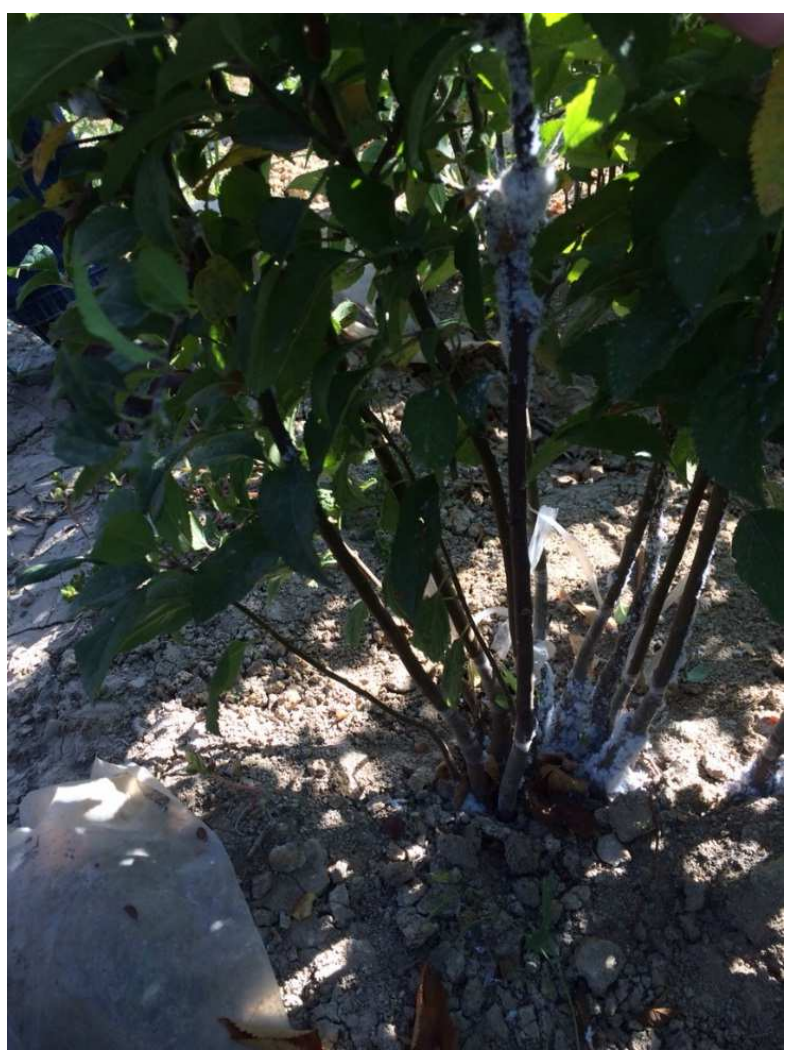

Fig. 1:Damage to seedlings of red woolly aphids (Eriosoma lanigerum Hausm.) in apple tree nurseries

The larvae of the first and second age pass the winter on the roots of trees, where from 68.7 to $82.4 \%$ of the total population are concentrated in Kazakhstan. A somewhat different pattern in the distribution of wintering aphid populations was observed in the foreststeppe of Ukraine. Here, from 53.9 to $62.4 \%$ are concentrated on the roots of trees, which is explained by higher air temperatures in Ukraine. It is also significant that from 56.3 to $72.8 \%$ of wintering aphid larvae, which are concentrated on the trunks of seedlings on the soil surface, are destroyed by the spring reactivation period. Sudden changes in air temperature and humidity are the main cause of destruction. In addition, the physiologically weakened portion of the aphid population is concentrated here. Spring reactivation of larvae occurs in spring at soil temperature in the crown region of $8-10^{\circ} \mathrm{C}$. The process of migration of larvae is long. According to our studies, the duration of the mass migration period was 7-10 days. In tree crowns, their trophic activity is activated at a temperature of $15-17^{\circ} \mathrm{C}$. The duration of the larval period of the overwintered generation is $18-27$ days. The least long period of development of one generation is observed in late June and mid-August. For Ukraine, this period is 10-12 days, for Kazakhstan - 12-14 days (Iperti, 1974; Hurpin, 1974; Lyon and Goldlin, 1974).

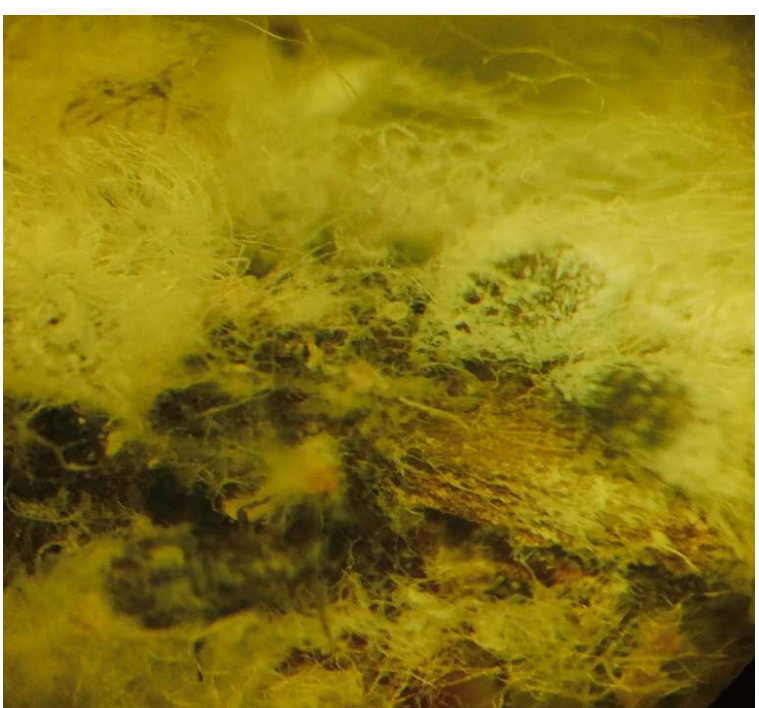

Fig. 2: Colonies of red woolly aphid (Eriosoma lanigerum Hausm.)

As a rule, the first spring virgins are particularly prolific. They sprout from 163.8 to 207.3 larvae. The fertility of females of the second and subsequent generations is $25-55$ larvae. During the growing season, in Ukraine the aphids give 9-10 generations, in Kazakhstan - 8-9. Generations are superimposed one on another (Fig. 2).

A characteristic feature of the biology of the woolly aphid is that its larvae are characterized by pronounced motor and trophic activity. They actively migrate to significant distances, creating new foci of infection. The trophic activity of larvae in the apple tree nurseries is manifested on the bark of branches and trunks and less often on roots.

The harmfulness of the woolly aphid is that as a result of mechanical trauma by the long proboscis of the bark and cambium of the apple tree, the introduction of a specific secretion of the salivary glands, characteristic nodular thickenings consisting of a loose tissue covered with a tender crust are formed. These formations proliferate; the goiters crack and deep ulcers are formed. Phytopathogens of fungal, bacterial and viral etiology penetrate into these formations. This is the primary gateway of infection for diseases such as bacterial blight of fruits and the causative agent is the Ervinia amylovora bacteria. The consequences for plantings and the development of pathogens are much more dangerous than the direct damage caused by larvae and the aphids' imago. As a rule, behind our observations, such plants die within 2-3 years. Woolly aphids are especially dangerous in nurseries, given that the phytophage firstly settles on young plants at the base of the sprouts, on cuttings of leaves.

Based on the studies conducted, we have identified a set of factors that shape the structure and dynamics of the woolly aphids' population in the apple tree nurseries and fruit-bearing gardens. 
Table 1: A set of factors forming the structure and dynamics of the woolly and other aphids' population (nurseries of forest-Steppe of Ukraine and Kazakhstan, 2014-2016)

\begin{tabular}{ll}
\hline Determinants & The degree of manifestation of factors and the interaction nature \\
\hline $\begin{array}{l}\text { The nature of the hydrothermal } \\
\text { conditions during the vegetation period }\end{array}$ & $\begin{array}{l}\text { HTI (hydrothermal index) in the period of vegetation in May - September is } \\
\text { in the range of 1.2-1.6; taking into account the level of adaptation of woolly } \\
\text { aphids, creates optimal conditions for the development of entomophages } \\
\text { Resting of row middles with nectariferous plants, as well as along the } \\
\text { perimeter of nurseries are the main factors hindering the development and } \\
\text { spread of woolly aphid } \\
\text { Leaf apparatus without signs of damage to phytopathogens, presence of root } \\
\text { canopy - factors contributing to the spread of root aphid } \\
\text { Competitive interactions in populations of woolly, green apple and elm-pear } \\
\text { aphids have been experimentally established. As a result, the harmfulness of } \\
\text { aphids increases } \\
\text { The regulatory activity of entomophages in the middle of summer is clearly } \\
\text { manifested. Populations of entomophages are the main cause of depressive } \\
\text { state of aphids in the summer period } \\
\text { High mortality rate of aphids, as well as entomophages when using chemical } \\
\text { insecticides. However, populations of woolly and other aphids quickly recover }\end{array}$ \\
of different species of aphids &
\end{tabular}

Table 1 presents the defining test characteristics of the biological factors obtained in the experiments in Ukraine and Kazakhstan. The six most important indicators have been characterized. It has been established that the synoptic situation determines the real potential for the spread of woolly aphid. Abnormal phenomena associated with both drought and intense precipitation limit the biological potential of the phytophages. However, the pronounced adaptive characteristics of the species, under any conditions, allow for the maximum implementation of the reproduction tactics of the species reproduction. This allows us to evaluate the effect of the synoptic factor, as a modifying effect on aphids.

The technological factors are among the reasons that keep aphids in certain parameters of the range. As part of the agrocenosis, vegetation diversity maximizes the high population level and maintenance of the species diversity of entomophagous populations. Among them aphelinus and predators - coccinellids, syrphids, gall midges - that trophically interact with aphids and prevent their mass distribution. The trophic optimum for aphids is a physiologically complete leaf apparatus - the bark of young growth. Stress factors are a complex of phytopathogens, primarily of fungal etiology - scab, powdery mildew. During epiphytoty periods, aphids experience significant stress anomalies, which limit their reproductive potential.

Interspecific competition increases the harmfulness of aphids until a certain period. Woolly aphids, with their feature to feed with the tree crown juice, withstand the expansion of other sucking phytophages, especially mites and scabs.

At the same time, as our studies have shown, natural populations of parasites, predators and, partly, entomopathogens play an important role in the dynamics of the number of woolly aphids. The latter include only the entopathogens of fungal etiology. As for the woolly aphids, besides the numerous representatives of carnivorous gall midges, syrphids, coccinellids, the special aphelinus entomophage plays an important and often crucial role. Introduced to the European part of the USSR from abroad in the late 1920s, the flies had quickly acclimatized and reduced the number and severity of the woolly aphid nearly everywhere. It is characteristic that most researchers note the rather high level of effectiveness of natural populations of aphelinus. Especially reasonable is the stage associated with the preliminary collection of diapausing populations of aphyllum-infected woolly aphids, preserving it under natural conditions and the subsequent dispersal of the biomaterial into the foci of the woolly aphid spread. It is stated that despite some technological difficulties associated with the collection, storage and the parasite expansion, the technique is quite technological and is justified by the high final result.

Literary sources and in-house studies have shown that aphelinus is a polyvoltine species. It infects larvae of different ages and woolly aphid imago. Depending on the conditions of the environment, it develops in 4-10 generations during the growing season. We established that the first-generation imago emerges in Ukraine in late March-early April at an average daily temperature of $14.5^{\circ} \mathrm{C}$ and relative humidity of $75-82 \%$. In Kazakhstan, these indicators are somewhat shifted. Spring reactivation of imago occurs in the middle of April at a temperature of $15.0-15.2^{\circ} \mathrm{C}$. In the spring, at an average daily temperature of $15-18^{\circ} \mathrm{C}$, the development of aphelinus of the first 2-3 generations is completed in 2630 days. When the temperature rises to $24-26^{\circ} \mathrm{C}$, the ontogenesis is completed in 15-17 days.

However, a very important feature of the biology and ecology of the species is that the aphelinus develops in the fall. Starting from the second decade of September, the flies' development slows down. Full diapause occurs only in the first decade of November, when the temperature 
drops to $7-8^{\circ} \mathrm{C}$. In autumn, in the presence of flowering nectar plants - phacelia, meadow clover, alfalfa, the gonads of females are fully functioning and intense motor activity and the search capacity of female parasites occur.

We investigated the daily rhythm of activity of the parasite imago. It was found that the maximum flight activity, victim search and its infection occurred between 9:30 a.m. and 1:00 p.m., at a temperature of $26-29^{\circ} \mathrm{C}$. At temperatures above $33^{\circ} \mathrm{C}$, the imago concentrates in the crown of trees, from the underside of the leaves. Imago activity resumes after 5:00 p.m. and before dusk.

A significant part of the research was dedicated to the substantiation of the possibility and expediency of using aphelinus by its spreading into tree crowns, as a method of biological protection of apple tree nurseries from woolly aphids. To do this, the branches harvested in the previous year with aphid colonies infected with aphelinus were expanded to the crowns of trees. The essential aspect in this case was that the branches with a parasite had been expanded on every third tree in the nursery at a rate of 25 to 35 imagos. Studies were conducted against the background of a high initial level of the woolly aphids' population, which exceeded 1.52.0 threshold levels. The process of detection, colonization and infection of aphids in colonies was also traced. In this case, colonies measuring from 0.5 to 2.0 $\mathrm{cm}$, females of aphelinus parasitized within 89.6-96.8\%. Females, after mating and supplementary feeding on nectar plants, detect colonies of aphids, by carefully monitoring the colony, starting from the periphery. A long process, which, in our opinion, involves determining the viability of aphid larvae, ends with the laying of eggs in the body of the aphid larvae. It was also established that at the periphery of the colony, the individuals had more often been infected than those that had concentrated in the center. This is due to the fact that in the center there was a significant amount of wax discharge of aphids. In fact, only this natural factor is characteristic of populations of aphids and prevented their infection with aphelinus.

It was also shown that aphelinus parasitized aphids on the root crown and roots of trees. The results of the three-year experiments are given in Table 2.

A rather variegated mosaic of the level of infection of woolly aphids' larvae with female aphelinus has been shown. By assessing the final effectiveness in protecting the nursery from the phytophagous of various technologies, we proceeded from the fact that the seasonal population dynamics was characteristic of the woolly aphids. Three peaks were actually established. There are two periods of activity and growth of population - in spring and autumn. The period of summer depression, as a consequence of deterioration of trophic factor for aphids, is accompanied by a long period of heat, a violation of the juice production balance and rhythm and also due to the activity of natural populations of parasites and predators during this period. It was with this factor in mind that three stages of aphelinus expansion were performed, with an emphasis on suppressing the activity of the woolly aphid in the second population peak. The materials in Table 2 illustrate the final results of the nursery protection technologies that have been implemented.

It has been established that regional insecticidal technologies on the reference version provided reliable protection of nurseries. However, a positive result was achieved by total extermination of the entire entomoacarocomplex. This is convincingly confirmed by the digital materials of the table. Indeed, throughout the growing season, the level of the woolly aphid infection with aphelinus on the chemical standard ranged from 4.7 to $12.7 \%$. Even less was the activity of other entomophages.

Table 2: The level of infection of woolly aphid populations with entomophages in apple tree nurseries (Kyiv and Almaty region, 2014-2016)

\begin{tabular}{|c|c|c|c|c|c|c|c|c|}
\hline \multirow[b]{2}{*}{ Year periods } & \multicolumn{2}{|c|}{$\begin{array}{l}\text { Option 1chemical } \\
\text { standard. Activity } \\
\text { of entomophages, } \\
\% \text { system }\end{array}$} & \multicolumn{2}{|c|}{$\begin{array}{l}\text { Option } 2 \text { Integrated } \\
\text { activity of } \\
\text { entomophages, } \%\end{array}$} & \multicolumn{2}{|c|}{$\begin{array}{l}\text { Option 3. Nectar } \\
\text { plants: Clover, alfalfa. } \\
\text { Expansion of aphelinus, } \\
\text { infected with aphids, \% }\end{array}$} & \multicolumn{2}{|c|}{$\begin{array}{l}\text { Control. Infected } \\
\text { with aphids, } \%\end{array}$} \\
\hline & Aphelinus & Other species & Aphelinus & Other species & Aphelinus & Other species & Aphelinus & Other species \\
\hline The first peak & 4.7 & 2.1 & 11.6 & 4.9 & 22.6 & 9.2 & 7.8 & 4.6 \\
\hline $\begin{array}{l}\text { in the aphid } \\
\text { population: } \\
\text { May and June }\end{array}$ & 5.3 & 3.4 & 8.8 & 5.4 & 28.4 & 11.3 & 10.2 & 10.4 \\
\hline Depression of & 5.2 & 2.8 & 9.7 & 8.4 & 57.3 & 17.4 & 32.4 & 19.3 \\
\hline woolly aphids: & 5.4 & 4.1 & 28.7 & 14.2 & 61.2 & 20.3 & 33.8 & 22.5 \\
\hline July, August & 5.7 & 3.0 & 34.5 & 11.6 & 59.2 & 12.6 & 26.7 & 10.2 \\
\hline The second & 12.7 & 10.2 & 20.7 & 14.3 & 64.2 & 26.4 & 31.8 & 20.9 \\
\hline peak in the & 11.9 & 9.5 & 15.9 & 10.7 & 58.6 & 19.8 & 26.2 & 18.6 \\
\hline $\begin{array}{l}\text { aphid population: } \\
\text { August, October }\end{array}$ & 8.8 & 4.6 & 11.3 & 8.5 & 42.8 & 16.3 & 14.3 & 15.7 \\
\hline
\end{tabular}


The opposite situation was observed in option 3 , where the aphelinus was expanded. The level of the aphids' infection with aphelinus ranged from 22.6 to $64.2 \%$. At the same time, the regularity is clearly visible, which indicates an increase in the intensity of parasitism by aphelinus females from the end of June and to the middle of October inclusive. Obviously, the determining factor in the summer depression of aphids was the activity of parasites and predators. If we add the useful activity of the entomophages of other systematic groups to this, the economic efficiency of aphelinus expansion was not inferior to the chemical standard.

It should be noted that apart from aphelinus, other types of entomophages have been identified in arthropod populations. After all, the final effectiveness of parasitism and predation of woolly aphids in the third option consisted of not only the infection rates of the woolly aphid with the aphelinus, but also with the other species. The total effectiveness of entomophages in the second peak of the woolly aphid population reached 78.4 and $96.6 \%$. The eggs, larvae and imagos of the coccinellidae woolly aphid were most effectively exterminated. We have noted such species as the sevenspotted ladybird (Coccinella 7 punctata L.), as well as the two-spotted (Chilocorus bipustulatus L.) and budlike (Ch. Renibipustulatus Sc.) chylocorus (Kazanok, 1972). Moreover, carnivorous two-winged were represented by five Syrphidae species, dominated by Syrphus ribesii L., Cheilosia conops, Ch. Ruralis, Ch. Vernalis, Eristalis tenax St., Melanostoma mellinum L. Non-specialized predators identified by us in the colonies belonged to the Anthocoridae, Miridae, Elateridae, Forficulidae families. Their activity was observed in options 2 and 3, as well as in control. In particular, in the control group, during the summer depression of woolly aphid, the activity of entomophages was particularly noticeable. The total infection rate of the phytophagus in this period was 51.7 and $56.3 \%$. The motor and trophic activity of the serpent flies (Raphidia flavipes L.) and the common earwig (Forficula auricularia L.) should also be noted.

\section{Discussion}

Expert analysis of the literature and in-house research have shown a significant negative economic role of sucking populations of phytophages, an integral part of the entomocomplex of nursery gardens. A woolly aphid typical representative of sucking phytophages - is characterized as a dominant species in the gardens and nurseries of Ukraine and Kazakhstan. The direct damage to the plantations, due to the feeding with larvae and imagos on the bark of trees, was clearly shown. There was also shown an indirect damage as a result of the colonization of aphids in the form of mass destruction of such plantations by phytopathogens. This resulted in a lethal outcome for plantings. It was also stressed that the destructive strategy, with the use of chemical insecticides, in addition to an obvious positive result was accompanied by negative consequences. This included the environmental unfriendliness, extermination of natural populations of entomophages and the formation of resistant populations of phytophages. Alternative techniques and technologies presuppose the conservation, activation and expansion of populations of entomophages, as well as the introduction of the most effective species.

An example with the expansion of a specific and unique entomophage - aphelinus - convincingly demonstrated the prospect of developing this biological protection resource. A high level of specific specialization of the parasite, only in relation to the woolly aphid, a significant number of generations, a negligible negative role of the hyperparasites are the main arguments for the viability and relevance of this technology. It must also be taken into account that the methods of expansion and enriching the agrocenoses of nurseries with aphelinus are not a one-time destruction method. The species is fixed in agrocenoses and the filial generations of the parasite are effective at the biocenotic level. The formation of the nectar plants conveyor creates the prerequisites for the formation of agrocenosis with its partial self-regulation.

\section{Conclusion}

It is shown that the woolly aphid gradually acquires the status of a dominant phytophage in the nurseries of pomaceous cultures of Kazakhstan and Ukraine, with a significant potential and real threat to plantings.

The parameters of seasonal development of the woolly aphid and its reaction to synoptic anomalies, the specificity and the nature of diapausing and wintering were established.

The factors of synoptic, ecological and biocenotic nature that form the structure and dynamics of the woolly aphid population were established experimentally.

The essential role of the trophic factor in this process was shown and the restraining role of entomophages in populations of woolly aphids was noted.

The principle possibility of regulating the population and protection of nurseries from woolly aphids using the method of settling the natural populations of the hymenopteran entomophage aphelinus was established.

The economic and biocenotic aspects of the implementation of this technology were discussed.

\section{Acknowledgement}

We thank our University for support.

\section{Author's Contributions}

All authors equally contributed in this work. 


\section{Ethics}

This article is original and contains unpublished material. The corresponding author confirms that all of the other authors have read and approved the manuscript and there are no ethical issues involved.

\section{References}

Audemard, H., 1976. Etude Demoecologigue du carpocapse (Laspeyresia pomonella L.) en verger de pommiers de la basse vallee du rhone possibilites d'organisation d'une lutte sntegree. These A L'universite Francois - Rabelais De Tows. DocteurIngenieur, pp: 365.

Boldyrev, M.I., S.A. Alekseyeva and D.A. Titov, 1989. System of Protection of Fruit Crops from Pests and Diseases. 1st Edn., VO Agropromizdat, Moscow, pp: 93.

Boldyreva, E.P., 1974. Biology, ecology and effectiveness of parasite of woolly aphid - aphelinus - in the Gissar valley of Tajikistan. Abstractof the Dissertation of the Candidate of Biological Sciences, Dushanbe, pp: 24.

Bonnemaison, L., 1974. Aphelinides. Les Organisms Verges Pommiers OILB/SROP, 3: 87-88.

Drozda, V.F. and A.O. Sagitov, 2015a. Potential and real threat to agrocenoses of Ukraine and Kazakhstan from a complex of phytophages in the context of global warming. Proceedings of the International Scientific Conference on Global Warming and Agrobiodiversity, (GWA'15), Tbilisi, Georgia, pp: 293-296.

Drozda, V.F. and A.O. Sagitov, 2015b. Characteristics of life strategies of carpophages in the context of protecting gardens in Ukraine and Kazakhstan. Proceedings of the International Scientific Conference on Innovative Ecologically Safe Plant Protection Technologies, (PPT'15), Kazakhstan, Almaty, pp: 98-108.

Drozda, V.F., 2017. Woolly aphids (Eriosoma lanigerum Haus.) - on the apple tree distribution, harmfulness, control of population. Procdeedings of the Materials of the International Scientific and Practical Internet Conference on Problems and Perspectives of Modern Agrarian Science, (MAS'88), Nikolaev, pp: 58-58.

Drozda, V.F., A.O. Sagitov, B.A. Kopzhasarov, M.O. Kocherga and S.D. Mel'nichuk et al., 2013b. The method of biological protection of gardens from pests. The Patent of the Republic of Kazakhstan No. 85162, Kazakhstan.

Drozda, V.F., A.O. Sagitov, B.A. Kopzhasarov, S.D. Melnichuk and K.M. Toleubaev, 2013a. The method of biological protection of pome fruits from the harmfulness of the woolly aphid Eriosoma lanigerun Hausm. The Patent of the Republic of Kazakhstan No. 84755, Kazakhstan.
Drozda, V.F., M.A. Kocherga, A.F. Goychuk, A.O. Sagitov and B.K. Kopzhasarov, 2014. The method of protection of apple gardens from parenchymasucking aphids. Patent of the Republic of Kazakhstan No. 86122, Kazakhstan.

Drozda, V.F., M.O. Kocherga and O.Í. Zagayko, 2014. Definitive principles of formation of agrocenoses of berries on an organic basis. Organic Production and Food Safety, Polissya Publishing House, Zhytomyr, Ukraine.

Hurpin, B., 1974. Organismes entomopathogenes. Les Organisms Verges Pommiers OILB/SROP, 3: 215-220.

Iperti, G., 1974. Les Coccinelles. Les Organisms Verges Pommiers OILB/SROP, 3: 111-121.

Izhevskiy, S.S., 1988. Scientific bases of introduction and application of entomophages of adventitious pests of plants. Abstract of the Dissertation of the Candidate of Biological Sciences, Leningrad, pp: 39.

Kazanok, G.T., 1972. Aphids - the pests of the apple tree in the lower dniester region and measures to combat them. Abstract of the Dissertation of the Candidate of Biological Sciences, Odessa, pp: 23.

Kolesova, D.A., 1979. Fighting aphids in a fruit garden. Recommendations. 1st Edn., Voronezh, pp: 52.

Leclant, F., 1974. Generalites sur les Pucerons Nuisibles au Pommier. Les Organismes Verger Pommiers OILB/SROP, 3: 81-86.

Lyon, I.P. and P. Goldlin, 1974. Tiefenou les syrphes predateurs des pucerons. Les Organisms Verges Pommiers OILB/SROP, 3: 163-170.

Pests of Agricultural Crops and Forest Plantations, 1987. Pests of Agricultural Crops and Forest Plantations. 1st Edn., Urozhay, Kiyev, pp: 440.

Rabasse, I. M.L., 1974. Aphelinides. Les Organisms Verges Pommiers OILB/SROP, 3: 88-90.

Vasil'yev, V.P. and I.Z. Livshits, 1984. Pests of Fruit Crops. 1st Edn., Kolos, Moscow, pp: 399.

Vereshchagin, B.V., A.V. Andreyev and A.V. Vereshchagina, 1985. Aphids of Moldova. 1st Edn., Chisinau: Stinta, pp: 160.

Vereshchagina, V.V., 1957. Ecology of woolly aphids and measures to combat it in Moldova. Proceedings of the Moldovan Institute of Horticulture. Chisinau, (IHC'57), Stiinta, pp: 255-266.

Zerova, M.D., V.I. Tolkanits and A.G. Kotenko, 1991. Entomophages of pests of apple trees in the southwest of the USSR. 1st Edn., Naukova Dumka, Kiev, pp: 276. 